\title{
Paralysed by politics, EPA delays spending any money on EMF research
}

\begin{abstract}
Washington. Research on the possible health risks of electric power lines and other sources of electromagnetic fields (EMFs) is so controversial that at least one US science agency has refused even to spend the research money it has been given. Officials at the Environmental Protection Agency (EPA) say that they lack a coordinated research programme, but other evidence suggests that the agency may be simply avoiding a political hot potato.
\end{abstract}

Although the US Department of Energy (DOE) has also delayed EMF funding out of fear of lending credence to those who say the problem is grave, critics of the government's research policies have focused on EPA, which received $\$ 1.9$ million from Congress for the fiscal year ending this month. That is a tiny sum compared to EMF research budgets elsewhere in the government and in industry, but not a penny of it has yet been spent.

Why is an agency with both an in-house research effort and a relatively large grants programme unable to spend less than $\$ 2$ million? Many people want to know.

The unspent money has drawn the attention of Representative George Brown (Democrat, California), chairman of the House science committee, and Representative James Scheuer (Democrat, New York), chairman of its subcommittee on the environment. They plan to send a letter to EPA asking about the funds when Congress returns next week from a month-long recess. The money has also attracted the notice of Senator Joseph Lieberman (Democrat, Connecticut), who told EPA last month that he might try to shift the money to the National Institute for Occupational Safety and Health for studies of cancer among police officers who use radar detectors. And a newsletter, Microwave News, entitled an editorial "Fear and Cowardice at EPA".

EPA officials say they have not spent the money because they do not want to waste it on marginal research. David Kleffman, deputy director of health research in the EPA Office of Research and Development, says that EPA has been reluctant to act without discussing the issue with a government-wide committee that includes officials from DOE, the White House and the Department of Health and Human Services. "The whole process, just because of the number of players, has turned out to be very cumbersome", he says.

But most observers believe that there is more to it than that. EPA started an EMF research programme in 1983 that was cancelled from above in 1986. At its peak, EPA had 27 full-time researchers and a budget of
\$3.5 million, almost as much as DOE, which has traditionally led the federal effort. Today, only a few EPA researcher are investigating EMF effects, working in such related fields as radiofrequency radiation.

Part of the reason for EPA's research troubles is that powerful officials in the administration and the scientific community doubt that EMF radiation poses a health risk. These sceptics include D. Allan Bromley, presidential science adviser, and Robert Adair, a prominent physicist and Bromley's former colleague at Yale Univer-

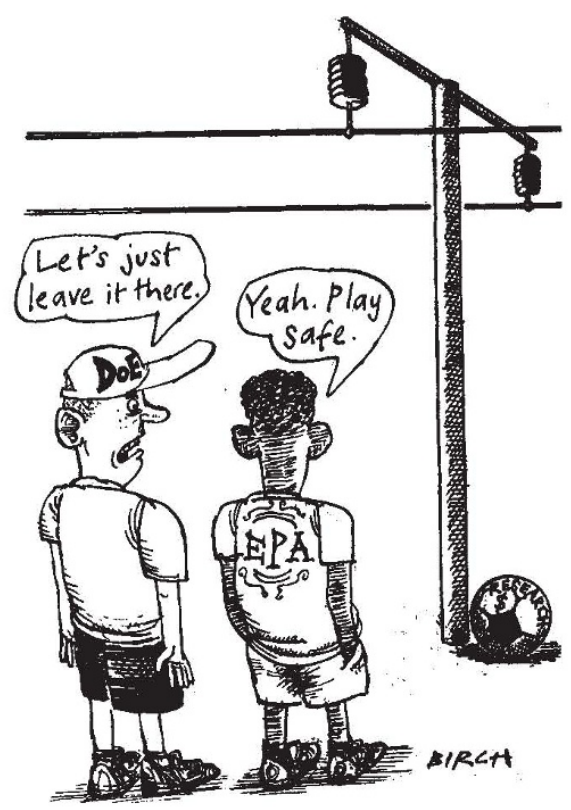

sity, who fear that the public will interpret federal funding as proof that a problem exists. It could also force utility companies and electronics manufacturers to spend millions of dollars to relocate power lines and to shield equipment. Bromley has met several times with EPA officials on the subject, especially after the agency released a controversial 1990 report labelling EMFs as "probable" carcinogens, and he has reportedly asked the agency to be less aggressive in pursuing the issue.

Ironically, the issue of EMFs finds industry, consumer activists and environmental groups in rare agreement: they all want more government research. The industryfunded Electric Power Research Institute (EPRI) is the largest player in the field, having spent about $\$ 50$ million, with plans to spend another $\$ 15$ million in 1992 . But although EPRI is considered relatively independent and has avoided most charges of industry bias, utility officials are convinced that the public will believe research dis- counting an EMF threat only if it comes from outside the industry, preferably from government-funded independent research.

Last year, Congress forced EPA back into the field by giving it $\$ 800,000$ that it did not request; the agency passed most of it on to the Health Effects Institute (HEI) in Cambridge, Massachusetts, for preparation of a research plan for an EMF research programme. But that approach backfired when HEI, an independent research organization funded half by industry and half by government and other grants, became enmeshed in a controversy over a report on asbestos risks. (Critics accused it of packing its scientific advisory panel with researchers connected with industry.) Although the final report was well received, the incident cost the institute its president and some of its credibility.

Seeking to avoid a similar controversy, HEI is moving ahead very slowly on the EMF project. Charles Powers, acting HEI president, says that the institute has convened a new advisory panel and expects to finish the report by the end of the year, more than a year late. And EPA, which had planned to give HEI the 1992 funding to set up an EMF research programme, has not yet sought another place to spend the money.

But while EPA has had so much trouble spending less than $\$ 2$ million, DOE has managed to operate a \$5.8-million EMF research programme with minimal controversy. It has even asked for an increase to $\$ 7.5$ million in fiscal year 1993. DOE plans to withhold spending $\$ 1.5$ million of its 1992 funding (its entire increase over 1991) until it receives the recommendations next month of an interagency steering group, but it is not expected to have trouble finding takers once it moves ahead.

Why is one agency being encouraged to expand its programme while another's efforts are being discouraged? Keith Florig, an analyst with Resources for the Future, believes that DOE's effort is simply less controversial. Most of DOE's EMF programme is in-house research on cellular models, with almost no funding for epidemiology. To date, the only research that has consistently provided cause for alarm has been epidemiological in nature.

"EPA comes at things with a presumption of environmental problems", says one congressional aide. "DOE, on the other hand, has an historic tendency to find nothing wrong - and in EMF they are simply not addressing the most relevant research questions." In this administration, this aide concludes, the best EMF research appears to be that which leaves the least wake.

Christopher Anderson 